\title{
HISTOLOGICAL ANALYSIS OF THE BIOCOMPATIBILITY OF THREE DIFFERENT CALCIUM HYDROXIDE-BASED ROOT CANAL SEALERS
}

\author{
ANÁLISE HISTOLÓGICA DA BIOCOMPATIBILIDADE DE TRÊS DIFERENTES CIMENTOS \\ OBTURADORES A BASE DE HIDRÓXIDO DE CÁLCIO
}

\begin{abstract}
Heloisa Helena PINHO VELOSO ${ }^{1}$, Roberto Alves do SANTOS ${ }^{1}$, Túlio Pessoa de ARAÚJO² Denise Piotto LEONARDI ${ }^{3}$, Flares BARATTO FILHO ${ }^{4}$
\end{abstract}

\author{
1- PhD, Full Professor, Department of Dentistry, University of Pernambuco, Pernambuco, Brazil. \\ 2- PhD, Full Professor, Department of Dentistry, Federal University of Paraíba, Brazil. \\ 3- MSc, Assistant Professor, Department of Dentistry, Positivo University Center, Curitiba, Paraná, Brazil. \\ 4- PhD, Full Professor, Department of Dentistry, University of the Area of Joinville, Santa Catarina, Brazil and Positivo University Center, \\ Curitiba, Paraná, Brazil.
}

Corresponding address: Dra. Denise Piotto Leonardi - Rua Gastão Câmara, 645 apto 303 Champagnat -Cep.: 80730-300, Curitiba, Paraná, Brazil - Tel: +55 (41) 3019-1378; Fax: +55 (41) 3335-2035 - e-mail: deleonardi@yahoo.com.br

Received: May 9, 2006 - Modification: June 19, 2006 - Accepted: October 2, 2006

\begin{abstract}
Q

bjective: To histologically evaluate the behavior of the subcutaneous tissue of rats after placement of polyethylene tubes filled with calcium hydroxide-based root canal sealers (Sealapex ${ }^{\mathrm{TM}}$, Apexit ${ }^{\mathrm{TM}}$ e Sealer $26^{\mathrm{TM}}$ ). Study design: The study employed 60 rats, which were divided into eight groups, being four experimental groups with 10 rats each, and four control groups with five rats. Analysis was conducted at 48 hours, 7, 21 and 60 days. Results: Histological analysis revealed that all sealers were irritant; however, the intensity varied between each sealer and as a function of time. At the initial periods (48 hours and seven days), all materials demonstrated similar outcomes, with inflammatory reaction from severe to moderate, respectively. At the final periods (21 and 60 days), the tissue reactions to the implants containing Sealapex ${ }^{\mathrm{TM}}$ displayed an active status yet with regression, compared to the Apexit ${ }^{\mathrm{TM}}$ and Sealer $26^{\mathrm{TM}}$. The control groups exhibited less inflammatory cells than the experimental groups, keeping a reaction status with regression. Conclusions: The results achieved in this study revealed that the Sealapex ${ }^{\mathrm{TM}}$ sealer was the most compatible, followed by Apexit ${ }^{\mathrm{TM}}$ and Sealer $26^{\mathrm{TM}}$. Uniterms: Biocompatible materials; Root canal obturation; Calcium hydroxide.
\end{abstract}

\footnotetext{
RESUMO

$I$

Introdução: O tratamento endodôntico tem seus procedimentos clínicos fundamentados em conhecimentos básicos, principalmente biológicos, cujo êxito do tratamento depende das condições dos tecidos da região apical e periapical, dos mecanismos de defesa orgânicos e da potencialidade de reparação das células. Diferentes materiais obturadores, com os mais diferentes componentes químicos, têm sido testados em busca de uma substância que tenha propriedades físico-químicas e principalmente biológicas ideais para perfeita vedação do canal radicular. Um fato importante referente aos insucessos nos tratamentos endodônticos diz respeito aos componentes tóxicos dos cimentos obturadores de canal, incluídos com o propósito de neutralizar as falhas de desinfecção durante o preparo do canal. Objetivo: Avaliar histologicamente o comportamento tecidual subcutâneo de ratos após implantes de tubos de polietileno preenchidos com cimentos obturadores de canal à base de hidróxido de cálcio (Sealapexâ, Apexitâ e Sealer 26â). Material e Método: Foram utilizados para este estudo 60 ratos, os quais foram divididos em oito grupos: quatro grupos experimentais, cada um com 10 ratos, e quatro grupos controle, com cinco ratos. Foram analisados em intervalos de 48 horas, 7, 21 e 60 dias. Resultados Os resultados da análise histológica mostraram que todos os cimentos foram irritantes, porém em intensidade que variaram entre si e em função do tempo. Nos períodos iniciais (48 horas e sete dias) todos os materiais exibiram resultados próximos, com quadro inflamatório entre severo e moderado, respectivamente. Nos períodos finais (21 e 60 dias), as reações teciduais aos implantes contendo o cimento Sealapexâ apresentaram quadro ativo, mas em fase involutiva, em relação aos cimentos Apexitâ e Sealer 26â. Os grupos controle apresentaram número de células inflamatórias inferior aos grupos experimentais, mantendo quadro reacional em fase involutiva. O método estatístico utilizado foi a análise de variância para que fosse feita uma comparação entre as médias. Conclusões: Conclui-se que o cimento Sealapexâ foi o mais biocompatível seguido pelo Apexitâ e Sealer 26â.

Unitermos: Cimentos endodônticos; Biocompatibilidade; Hidróxido de cálcio.
} 


\section{INTRODUCTION}

The field of Endodontics, especially as regards the materials and techniques, has been presenting considerable advances in the last years, providing the professionals with more safety for accomplishment of root canal filling.

The basis of clinical procedures of endodontic techniques is the basic knowledge, and a successful treatment depends on the conditions of the apical and periapical tissues, immune mechanisms and potential of cell regeneration. Different filling materials with diverse chemical components have been tested in the search for some substance that presents ideal physicochemical and mainly biological properties for a perfect root canal sealing. An important aspect related to unsuccessful endodontic therapies is related to the toxic components of root canal sealers, which are included in an attempt to neutralize any deficiencies in the disinfection accomplished during root canal preparation. These sealers are able to mask symptoms that might appear soon after treatment ${ }^{3}$.

Ingle and Taintor ${ }^{5}$ (1985) stated that the initial reaction of the periapical tissues to all sealers is inflammatory, yet cell regeneration occurs as the sealers harden, unless they continue to disintegrate with release of any toxic components. Root canal sealers are needed to fill unavoidable gaps between the solid filling materials and the root canal walls, and should be both biologically acceptable and able to bond to dentin ${ }^{15}$.

The zinc oxide-eugenol-based root canal sealers, long employed for root canal filling, display quite satisfactory clinical outcomes. However, the biocompatibility of these materials is impaired by the presence of eugenol, which has cytotoxic properties. The modern Endodontics has been struggling to eliminate certain empirically based myths with the search for a material that meets the ideal requirements as regards the biological and physicochemical properties. Within this context, the calcium hydroxide-based sealers were introduced and have been increasingly employed; however, the presence of calcium hydroxide in a product does not assure its therapeutic properties, since there are also other components in root canal sealers.

Thus, the aim of this investigation was to histologically evaluate the behavior of the subcutaneous tissue of Wistar rats after contact with calcium hydroxide-based root canal sealers with different chemical compositions (Sealapex, Sealer 26, Apexit), in order to provide useful information for clinical studies addressing the selection of a more biocompatible material.

\section{MATERIALAND METHOD}

The present investigation utilized 60 male Wistar rats (Rattus norvegicus, albinus), all young adult animals (about 60 days) weighing 180 to 220 grams, obtained from the laboratory animal of the Research Center Aggeu Magalhaes (FIOCRUZ), Recife, PE, Brazil. The use of animals for this research was approved by the local Ethics Committee for animal research, and NIH guidelines stated in the "Principles of laboratory animal care" were followed; the study design was approved by the Ethics Committee under approval report n. 183/03.

The animals were divided into eight groups, being four experimental and four control groups. The experimental groups contained 10 rats each, and the control groups had five rats each. The groups were analyzed in 48 hours (Group 1); 7 days (Group 2); 21 days (Group 3) and 60 days (Group 4).

The animals were anesthetized with intraperitoneal sodium Thiopental (Cristalia Produtos Quimicos e Farmaceuticos Ltda, Itapira, Sao Paulo, Brazil), 50mg/kg of weight, one at a time in order to reduce suffering, followed by trichotomy on the dorsal area. Longitudinal incisions measuring approximately $5 \mathrm{~mm}$ were performed on three predetermined areas outside the midline (two at the scapular and one at the right pelvic area). Thereafter, tissue dissection was laterally accomplished with blunt-pointed scissors with the achievement of three surgical areas with subcutaneous access, in order to allow subcutaneous placement of the implants and thus avoid dilaceration (at $2 \mathrm{~cm}$ from the incision line).

The sealers were then prepared according to the manufacturers' instructions and placed inside polyethylene tubes measuring $10 \mathrm{~mm}$ in length and $1.5 \mathrm{~mm}$ in internal diameter, with one end closed. Following, the specimens with the study materials were inserted with pliers in the surgical areas according to the type of material to be analyzed, as follows: Sealapex ${ }^{\mathrm{TM}}$ (Sybron/ Kerr, Industria e Comercio Ltda. Sao Paulo, Brazil) at the right scapular area; Sealer 26 ${ }^{\mathrm{TM}}$ (Dentsply, Petrópolis, Rio de Janeiro, Brazil) at the left scapular area; Apexit ${ }^{\mathrm{TM}}$ (Vivadent, Schaan, Liechenstein) at the right dorsal pelvic area.

Thus, three dorsal implants were placed in each animal of the eight groups, being two in the scapulae and the other in the pelvis. The tubes in the experimental group contained the root canal sealers under investigation, and the control group received implantation of empty tubes in the same predetermined areas. Afterwards, the rats were returned to their cages and kept under observation until sacrifice.

After the experimental periods of 48 hours (experimental group 1, control group 1), 7 (experimental group 2, control group 2), 21 (experimental group 3, control group 3) and 60 days (experimental group 4, control group 4), the rats were anesthetized and sacrificed and the tissue around the implant was surgically removed, including removal of enough surrounding tissue.

After fixation of the specimens in Bouin's liquid (Histology Laboratory of UPE/PE), the properly identified tissue blocks containing the polyethylene tubes were trimmed and embedded in paraffin after removal of the tubes.

From the 180 identified blocks achieved, the 120 blocks from the experimental group were separated according to the period and material analyzed, and the control blocks were separated according to the period. The blocks were submitted to microtomy on a Leitz Wetzlar microtome (Germany) from the Department of Morphological Sciences 
(Histology Laboratory of UPE/PE).

Each block was sectioned in 6- $\mu$ m thick sections, longitudinally to the tube. Five non-adjacent sections from different areas were randomly selected, which corresponded to five slabs. The 900 slabs obtained and prepared were stained with Hematoxylin and Eosin, Gomori's Trichrome and Picrosirius as described by Maia ${ }^{9}$, (1979) Bancroft and Stevens ${ }^{1}$ (1982) and Mota $^{10}$ (1985).

Microscopic analysis was conducted on a binocular light microscope (OLYMPUS - Japan) with immersion objective $(1,000 x)$. The reactions were investigated at the interface between tissue and material at the open end of the tube and analyzed by an examiner (histologist) blinded to the study. Reading of the number of inflammatory cells and fibroblasts was performed by means of division of each slab into five fields. It should be noticed that, depending on the extension of reaction, one or two fields might not present inflammation and thus the number zero would be recorded for each inflammatory cells. Means were recorded for each type of cell for each animal after reading of five microscopic fields on each slab related to each material and group.

Evaluation of the degree of cell infiltrate was conducted by sum of the means of the different types of inflammatory cells for all five fields for each group and material, following the classification suggested by Wolfson and Seltzer ${ }^{18}$ (1975) and adopted by Leal, et al. ${ }^{7}$ (1988) with slight modifications: Up to 49 cells: Mild; From 50 to 99 cells: Medium or discreet; From 100 to 249 cells: Moderate; Equal to or above 250 cells: Severe.

\section{RESULTS}

Microscopic evaluation at the study periods did not reveal any condition of inflammatory and/or infectious nature on the surgical sites prepared to receive the implants. Analysis of the skin surrounding the tubes revealed absence of exudate, as well as adherence of tissues in groups 3 and 4. The specimens containing the implants with sealers Sealapex, Apexit and those of the control group presented normal color around them; however, the implants filled with Sealer 26 were often surrounded by an hyperemic and edematous area, besides the presence of a black material inside the tube. The mean and standard deviation between groups were calculated from the data achieved by using the variance analysis method.

At 48 hours (Group 1), the mean number of neutrophils was remarkably higher for Sealer 26 (image 3a) and less high for Apexit (image 2a). This group did not exhibit giant cells, being plasma cells observed only for the material Apexit, whose mean value was 1.00 . The variability was high between fields in this group for the plasma cells for the material Apexit.

At 7 days (Group 2), the mean number of neutrophils was lower for the Sealapex (image 1b) and higher for Sealer 26 (image 3b), with respective values of 1.00 and 22.40. The presence of plasma cells and giant cells was only observed for Sealapex (image 1b). The variability between fields was very high in this group for neutrophils, plasma cells and giant cells for the Sealapex.

At 21 days (Group 3), the mean number of neutrophils was quite reduced, with a maximum value of 1.60 for Sealer 26 (image 3c). The highest mean numbers were 14.40 for lymphocytes for Sealer 26, and 13.00 for macrophages for the Apexit (image 2c), with no observation of presence of neutrophils for the Sealapex (image 1c). There was a large variability in this group for the plasma cells for the Sealapex, and neutrophils and plasma cells for the Apexit.

At 60 days (Group 4), the mean number of cells was relatively low, except for the macrophages for Sealer 26 (image $3 d)$, with a mean of 30.33. The presence of neutrophils was only recorded for the Apexit (image 2d). The variability was large in this group for the plasma cells for Sealapex and giant cells for the Apexit.

Comparison between the experimental groups for the mean of fields reveals the following:

- the mean number of neutrophils was significantly higher for the animals in Group 1 than the other groups, for any material;

- the mean number of lymphocytes and macrophages was slightly higher for the group of animals killed at 7 days (Group 2) compared to the animals in the other three experimental groups, except for the macrophages in Group 3 for Apexit and lymphocytes for Sealer 26, which also had reasonably high values. The maximum mean number of lymphocytes was found for the Sealapex in Group 2, with a value of 16.20; for the macrophages, this maximum value was observed for Apexit in Group 2, with a value of 23.67;

- plasma cells were not observed for the Sealapex and Sealer 26 in Group 1 nor for Apexit and Sealer 26 in Groups 2 and 4 ;

- giant cells were only observed for the Sealapex in Group 2, all three materials in Group 3 and Apexit and Sealer 26 in Group 4. The maximum mean value was 4.40 between fields.

With regard to the means of fields for the control groups, the following was observed:

- the mean occurrence of neutrophils was higher for Group 1, followed by Group 2 with respective values of 25.4 and 16.33. For Group 3 and 4, the occurrence of this type of cell was reduced;

- the mean presence of lymphocytes with values of 12.00 was slightly higher for Group 3 than for the other groups;

- there were no plasma cells and giant cells in any control group;

- the variability between fields was remarkably high for the neutrophils in Group 1.

Table 1 presents the total number of inflammatory cells according to group and material, and the classification of cell infiltrate.

Thus, it was possible to observe that, for the experimental groups, the results of cell infiltrate were as follows: for Group 1 , all three sealers were classified as severe inflammatory reaction; for Group 2 as moderate; for Group 3 as medium or discreet for Sealapex and moderate for the other two sealers; and for Group 4, as mild inflammatory reaction for Sealapex and moderate for the other two sealers. The Sealer 26 presented the highest amounts of inflammatory cells in all 
groups, thus presenting the worst performance. For Groups 1 and 2, the Apexit had the lowest amounts of inflammatory cells, whereas for Groups 3 and 4 the lowest amounts of cells were found for the Sealapex. All control groups were classified as moderate at most. In these groups, the results according to the criteria established were moderate inflammatory reaction for Group 1, medium for Group 2 and mild for Groups 3 and 4.

The figures present the histological sections for the sealers Sealapex (Figure 1), Apexit (Figure 2) and Sealer 26 (Figure 3), at the four study periods.

\section{DISCUSSION}

The development of scientific knowledge in medical and related areas has long been employing animal investigations. The frequent utilization of rats as a research tool is based on aspects such as easy handling, relatively short vital cycles, and well-known anatomy, physiology and genetic variations. $^{12}$

According to Leal, et al. ${ }^{7}$, (1988) Yesilsoy, et al. ${ }^{19}$ (1988) and Soares, et al. ${ }^{14}$, (1990) who analyzed the performance of the Sealapex sealer and observed the occurrence of diffuse calcifications in the presence of this sealer, an axiom for every material for biological application is not to be cytotoxic, and thus the ideal response of the periapical tissues to the endodontic therapy would be the formation of biological sealing of the apical foramen by deposition of newly formed cementum. Leal et al. ${ }^{7}$ (1988) investigated the biocompatibility of Sealapex, as well as CRCS, Fill Canal and $\mathrm{N}$-Rickert in the subcutaneous tissue of rats and demonstrated that, in general, all sealers were fairly irritant to the connective tissue; however, the Sealapex at seven days yielded a moderate inflammatory reaction, with a mild inflammatory reaction at 21 and 60 days, indicating a tendency toward repair. In agreement with these findings, Silva, et al. ${ }^{13}$ (1997) studied the biological behavior of Sealapex, CRCS, Apexit and Sealer 26 sealers in the connective tissue and peritoneal cavity of isogenic mice and revealed a large increase in the number of polymorphonuclear leukocytes at the initial 2- to 4-day period in all sealers analyzed when compared to the control group. Comparison of the sealers to each other revealed fewer neutrophils at the initial stage for the Sealapex sealer in relation to the other sealers analyzed. Despite somewhat different from the present outcomes at the initial 48-hour period, on which the Apexit sealer displayed fewer neutrophils when compared to the Sealapex, these findings are in agreement with the present outcomes at the subsequent periods, which displayed a progressive reduction in the number of inflammatory cells, characterizing an evolution toward repair. On the other hand, the findings of Nassri, et al. ${ }^{11}$, (2003) who investigated the biocompatibility of Sealapex and Apexit sealers in the subcutaneous connective tissue of rats, fully corroborate the present results, on which the Apexit displayed a much more aggressive tissue reaction than the Sealapex.
Differently, Zmener, et al. ${ }^{19}$ (1988) conducted a quantitative study on which the tissue response to the Sealapex sealer was compared to the CRCS sealer, a calcium hydroxide-based sealer containing eugenol, and observed that the tissue reaction to the Sealapex sealer displayed a progressive increase after 30 and 90 days, with the

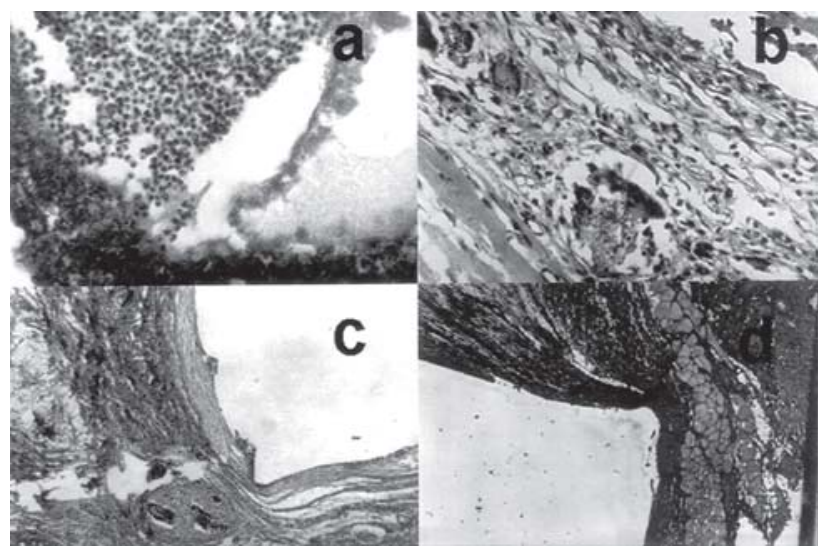

FIGURE 1- Sealapex - a) 48 hours (200x); b) 7 days (200x); c) 21 days (20x); d) 60 days (20x); Star: giant cells; Arrow: neutrophils

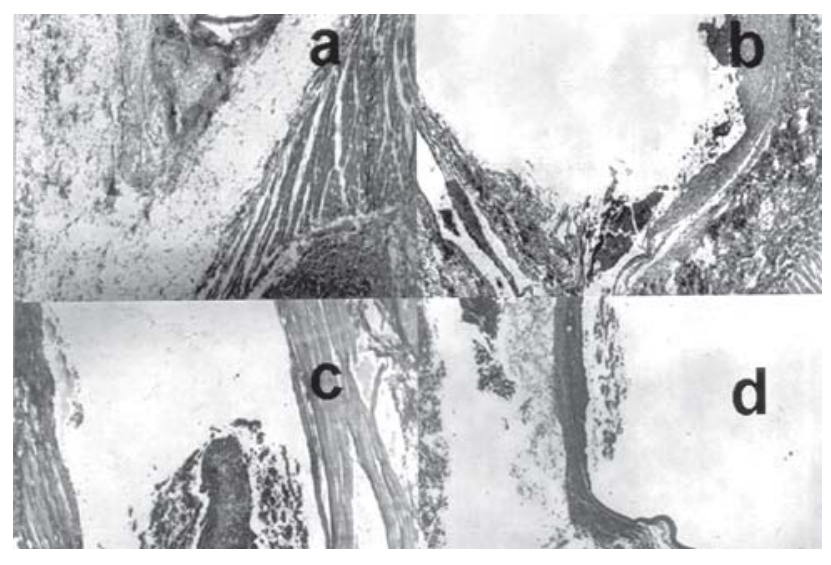

FIGURE 2- Apexit - a) 48 hours (20x); b) 7 days (20x); c) 21 days $(20 x)$; d) 60 days (20x); Arrow: neutrophils; M: macrophages

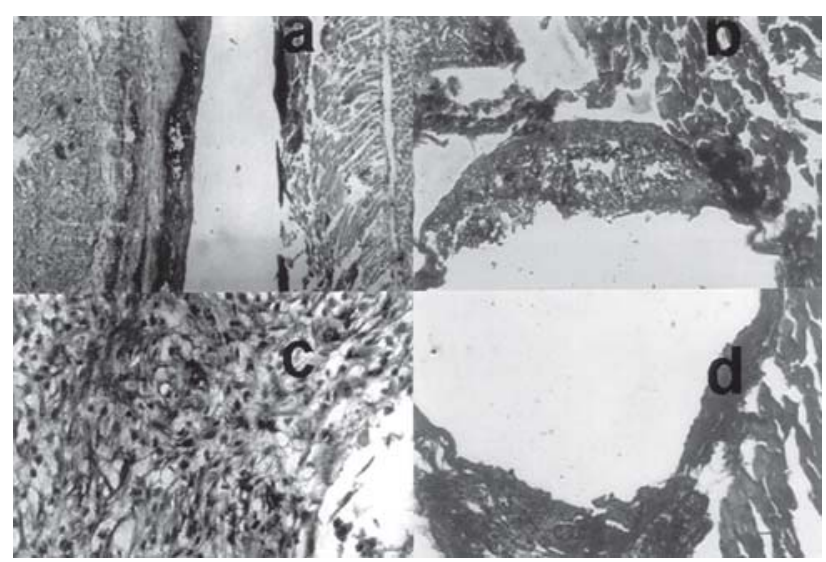

FIGURE 3- Sealer 26 - a) 48 hours (20x); b) 7 days (50x); c) 21 days (200x); d) 60 days (50x); Arrow: neutrophils; M: macrophages 
persistence of a granulomatous reaction with presence of black particles in the cytoplasm of macrophages, which the authors believed to be particles of titanium dioxide and which would be associated to these outcomes because of the high phagocytic activity. However, Holland ${ }^{4}$ concluded that the Sealapex was less toxic when compared to zinc oxideeugenol-based sealers, yet also highlighted the presence of titanium dioxide in the cytoplasm of macrophages. Even though the results of Zmener, et al. ${ }^{21}$ (1990) have confirmed that the black particles observed inside macrophages and giant cells in investigations on Sealapex are in fact composed of titanium and barium dioxides, the same investigations concluded that removal of these components from the sealer composition surprisingly increased the inflammatory reaction.

Histological analysis of this study clearly demonstrates the more aggressive reaction of the Apexit sealer compared to Sealapex, corroborating the findings of Nassri, et al. ${ }^{11}$ (2003). However, the in vitro analysis conducted by Beltes, et al. ${ }^{2}$ (1995) stated that the Apexit sealer is less cytotoxic when tested in cell suspension, demonstrating a better performance compared to the Sealapex sealer.

In agreement with the present study, Silva, et al. ${ }^{13}$ (1997) observed the presence of tissue necrosis in contact with material remnants and a reduced number of polymorphonuclear cells at the intermediate and final periods, which was more pronounced for the Sealapex sealer, followed by Apexit and Sealer 26.

On the other hand, Sealer 26 is derived from AH26, to which calcium hydroxide was added. The AH26 was a widely investigated root canal sealer, especially as regards its biological properties. The most irritant among all components of AH26 was found to be the A bisphenol ether. ${ }^{8}$ The unsatisfactory results obtained in the present investigation for Sealer 26, which displayed a severe inflammatory reaction at the initial 48-hour period and moderate reaction at the further 7-, 21- and 60-day periods were in accordance with the findings of Silva, et al. ${ }^{13}$ (1997) on which the histological outcomes demonstrated that the reactions to Sealer 26 yielded an intense neutrophilia at the initial periods, inducing severe inflammation and degeneration. However, these findings are in disagreement with those of Jacobovitiz ${ }^{6}$ (1996) on the subcutaneous tissue of rats, which found that Sealer 26 was less irritant than the CRCS and Apexit. This corroborates the outcomes observed by Valera ${ }^{16}$, (1995) who investigated the biocompatibility of Sealapex, Sealer 26, Apexit and Ketac Endo sealers, and found that Sealer 26 presented the mildest inflammatory reaction at 90 days. This study highlighted the need to increase the experimental periods up to 90 days, since all experimental groups at the 60-day period exhibited material remnants contacting the tissues, thus indicating that they were still being repaired. An interesting aspect is the fact that the biological properties reflect the ability of the material to be inert, yet if this is not true, the material must contain substances that may be more easily phagocyted and digested and less dispersed, thus leading to a better response as to tissue repair.

TABLE 1- Number of inflammatory cells according to group and material

\begin{tabular}{|c|c|c|c|c|}
\hline \multirow[b]{2}{*}{ Type } & \multirow[b]{2}{*}{ Group } & \multicolumn{3}{|c|}{ Statistics } \\
\hline & & Material & Number of cells & Classification \\
\hline \multirow[t]{3}{*}{ Experimental } & 1 & Sealapex & 521 & Severe \\
\hline & & Apexit & 446 & Severe \\
\hline & & Sealer 26 & 589 & Severe \\
\hline \multirow[t]{3}{*}{ Experimental } & 2 & Sealapex & 191 & Moderate \\
\hline & & Apexit & 152 & Moderate \\
\hline & & Sealer 26 & 247 & Moderate \\
\hline \multirow[t]{3}{*}{ Experimental } & 3 & Sealapex & 95 & Medium (discreet) \\
\hline & & Apexit & 111 & Moderate \\
\hline & & Sealer 26 & 181 & Moderate \\
\hline \multirow[t]{3}{*}{ Experimental } & 4 & Sealapex & 31 & Mild \\
\hline & & Apexit & 105 & Moderate \\
\hline & & Sealer 26 & 127 & Moderate \\
\hline Control & 1 & - & 191 & Moderate \\
\hline Control & 2 & - & 94 & Medium (discreet) \\
\hline Control & 3 & - & 31 & Mild \\
\hline Control & 4 & - & 22 & Mild \\
\hline
\end{tabular}




\section{CONCLUSIONS}

1. All sealers were irritant, yet the intensity varied between each sealer and as a function of time;

2. The Sealapex ${ }^{\mathrm{TM}}$ sealer was the most biocompatible, followed by the Apexit ${ }^{\mathrm{TM}}$ and Sealer $26^{\mathrm{TM}}$;

3. The Sealer $26^{\mathrm{TM}}$ induced a larger number of inflammatory cells at all study periods.

\section{REFERENCES}

1- Bancroft JD, Stevens A. Theory and practice of histological techniques. $2^{\text {nd }}$ ed. London and New York: Churchill Livingstone; 1982.

2- Beltes P, Koulaozidou E, Kotola V, Kortasaris AH. In vitro evaluation of the citotixic of calcium hydroxide based root canal sealers. Endod Dent Traumatol. 1995;11:245-9.

3- Briseño BM, Willershausen B. Root canal sealer cytotoxicity on human gingival fibroblasts. J Endod. 1990;16:383-6.

4- Holland R. A histological comparison of periapical inflammatory and neural responses to two endodontic sealers in the ferret. Arch Oral Biol. 1994;39:539-44.

5- Ingle JI, Taintor JF. Endodontia. $3^{\text {rd }}$ ed. Rio de Janeiro: Guanabara; 1985.

6- Jacobovitiz M. Avaliação da reação do tecido conjuntivo subcutâneo do rato ao implante de cimentos endodonticos á base de hidróxido de cálcio. Araraquara, SP, Brazil, 1996. (Dissertação de MestradoUniversidade Estadual Paulista UNESP).

7- Leal JM, Holland, R, Esberard RM. Sealapex, CRCS, Fill canal e NRickert, estudo da biocompatibilidade em tecido conjuntivo subcutâneo do rato. Odont Clin. 1988;2:7-14.

8- Lia RCC, Silva FACF, Benatti-Neto C, Oliveira MRB. Análise histológica comparativa dos componentes do cimento AH26. Rev Odont UNESP. 1988;17:7- 18.

9- Maia V. Técnica histológica. $2^{\text {nd }}$ ed. São Paulo: Atheneu; 1979.

10 - Mota DL. Contribuição ao estudo histológico dos intestinos de Bradypus Tridactylus. São Paulo, SP, Brazil,1985. (Dissertação de Mestrado -Universidade de São Paulo).

11 - Nassri MRG, Lia RCC, Bombana AC. Análise da resposta tecidual de dois cimentos endodonticos. J Appl Oral Sci. 2003;11:9-14.

12- Ribeiro SML, Campos P, Tirapegui J. O rato como animal de laboratório: Histórico, dados biológicos e análise crítica de seu uso. Rev Farm Bioq Univ S Paulo. 1995;31:21- 8.

13- Silva LAB, Leonardo MR, Faccioli LH, Figueiredo F. Inflammatory response to calcium hydroxide based root canal sealers. J Endod. 1997;23:86-90.

14- Soares I, Goldeberg F, Massone EJ, Soares IM. Periapical response to two calcium hydroxide-containing endodontic sealers. J Endod. 1990;16:166-9.

15- Syrjänen S, Möller B, Hensten-Pettersen A. Macrophage response and hemolytic activity caused by the powder component of endodontic sealers. J Endod. 1985;11:294-300.
16- Valera MC. Estudo da compatibilidade biológica de alguns cimentos endodonticos à base de hidróxido de cálcio e um cimento de ionômero de viro. Avaliação do selamento marginal apical e análise morfológica por microscopia de força anatômica. Araraquara, SP, Brazil,1995. (Tese de Doutorado - Universidade Estadual Paulista UNESP).

17- Valera MC, Leonardo MR, Consolaro A. Biological compatibility of some types of endodontic calcium hydroxide and glass ionomer cements. J Appl Oral Sci. 2004;12:294-300.

18- Wolfson EM, Seltezer S. Reaction of rat connective tissue to some gutta percha formulations. J Endod. 1975;1:395-402.

19- Yesilsoy C, Koren LZ, Morse DR, Kobayashi C. A comparative tissue toxicity evaluation of established and newer root canal sealers. Oral Surg Oral Med Oral Pathol. 1988;65:459-67.

20-Zmener O, Guglielmotti MB, Cabrini RL. Biocompatibility of two calcium hydroxide-based endodontic sealers: A quantitative study in the subcutaneos connective tissue of the rat. J Endod. 1988;14:22935 .

21-Zmener O, Guglielmotti MB, Cabrini RL. Tissue response to a experimental calcium hydroxide-based endodontic sealer: a quantitative study in subcutaneous connective tissue of the rat. Endod Dent Traumatol. 1990;6:66- 72. 